\section{Is pyridylmethyl group of imidacloprid replaceable with fluoroalkyl moiety as a hydrogen-bond acceptor?}

\author{
Shinzo KAGABU, * Eiji AOKI and Ikuya OHNO \\ Department of Chemistry, Faculty of Education, Gifu University, \\ Gifu 501-1193, Japan
}

(Received October 23, 2006; Accepted December 27, 2006)

Variable fluoroalkyl groups were introduced to 2-( $N$-nitroimino)imidazolidine and the insecticidal potency against the green peach aphid, the tobacco cutworm and the cucurbit leaf beetle was assessed. The activity of most of the compounds was modest, except for the 3-fluoropropyl derivative showing the apparent insecticidal activity against the aphid and the leaf beetle at 100 ppm. The protrusion of the fluoropropyl derivative may be taken as the H-bond functionality of this group similar to the pyridylmethyl group of imidacloprid in the electronic and geometrical respects. However, judging from the obviously lower activity than imidacloprid, the fluoroalkyl group will not compatible with pyridylmethyl as an activator. (C) Pesticide Science Society of Japan

Keywords: fluorocarbon, imidacloprid, insecticidal activity, Hbonding.

\section{Introduction}

Neonicotinoids have become a major insecticide class since imidacloprid was launched on the market. The finding of the chloropyridylmethyl group as an activator will be the key to the development of this class. ${ }^{1)}$ Following the pyridyl group, heterocycles such as thiazole and tetrahydrofuran were found to show the similar activation. The general aspect is that the hydrogen-bond (H-bond) involving the nitrogen or oxygen atom at the appropriate position in the heterocycle plays a crucial role in activation. ${ }^{2)}$

The introduction of fluorine into active ingredients is described as an important concept for modern crop protection product. ${ }^{3)}$ Several unique features of the $\mathrm{C}-\mathrm{F}$ bond, e.g. possible $\mathrm{H}$-accepting ability of the highly electronegative fluorine atom, ${ }^{4)}$ are thought to impart profitable properties to the molecule.

In this context, we introduced fluoroalkyl groups to the 2-( $N$ nitroimino)-imidazolidine skeleton and assessed the insecticidal activity toward the green peach aphid, the tobacco cutworm and

\footnotetext{
* To whom correspondence should be addressed.

E-mail: kagabus@gifu-u.ac.jp

Published online March 20, 2007

(C) Pesticide Science Society of Japan
}

the cucurbit beetle in order to see if the fluoroalkyl moiety elicits an insecticidal effect comparable to the existing neonicotinoids bearing "ordinary" H-bonding accepting atoms.

\section{Materials and Methods}

\section{Preparation of compounds}

All melting points (mp) are uncorrected. NMR spectra were obtained with a Varian Gemini $2000 \mathrm{C} / \mathrm{H}(400 \mathrm{MHz})$. Chemical shifts were recorded in $\delta$ (ppm) and the coupling constant $J$ in Hz. Mass spectra were recorded with a JEOL JMS-700.

The preparation of 1-(3-fluoropropyl)-2-( $N$-nitroimino)imidazolidine (3) is typical of the procedure used. A suspension of 2nitroimino-imidazolidine $(260 \mathrm{mg}, 2.0 \mathrm{mmol})$, 1-bromo-3-fluoropropane $(282 \mathrm{mg}, 2.0 \mathrm{mmol})$, cesium carbonate $(600 \mathrm{mg}, 1.84$ mmol) and cetyltrimethylammonium chloride (about $20 \mathrm{mg}$ ) in acetonitrile $(30 \mathrm{ml})$ was heated at the reflux temperature for $6 \mathrm{hr}$. The cooled reaction mixture was filtered and the acetonitrile was distilled off. The residual pale yellow liquid was subjected to preparative thin-layer chromatography $\left(\mathrm{SiO}_{2}\right.$; chloroform/ethanol 9:1). Product was obtained as colorless crystals. Yield: $238 \mathrm{mg}$ (63\%). Mp. $73^{\circ} \mathrm{C} .{ }^{1} \mathrm{H}-\mathrm{NMR} \delta\left(\mathrm{CDCl}_{3}\right): 2.00\left(2 \mathrm{H}, \mathrm{dm}, J_{\mathrm{H}-\mathrm{F}}=\right.$ $19.5 \mathrm{~Hz}), 3.50\left(2 \mathrm{H}, \mathrm{t}, J_{\mathrm{H}-\mathrm{H}}=7.3 \mathrm{~Hz}\right), 3.68(2 \mathrm{H}, \mathrm{m}), 3.82(2 \mathrm{H}, \mathrm{m})$, $5.30\left(2 \mathrm{H}, \mathrm{dt}, J_{\mathrm{H}-\mathrm{F}}=46.9, J_{\mathrm{H}-\mathrm{H}}=5.8 \mathrm{~Hz}\right), 8.11(1 \mathrm{H}, \mathrm{bs}) ;{ }^{13} \mathrm{C}-\mathrm{NMR}$ $\delta\left(\mathrm{CDCl}_{3}\right): 28.0\left(\mathrm{~d}, J_{\mathrm{C}-\mathrm{F}}=19.1 \mathrm{~Hz}\right), 41.3\left(\mathrm{~d}, J_{\mathrm{C}-\mathrm{F}}=4.6 \mathrm{~Hz}\right), 41.4$, 45.9, 81.0 (d, $\left.J_{\mathrm{C}-\mathrm{F}}=164.8 \mathrm{~Hz}\right)$, 161.1. $\mathrm{MS} m / z(\%): 190\left(\mathrm{M}^{+}, 7\right)$, 144 (72), 124 (27), 42 (100).

1-Propyl-2-(N-nitroimino)imidazolidine (1). Mp. $110-111^{\circ} \mathrm{C}$. ${ }^{1} \mathrm{H}-\mathrm{NMR} \delta\left(\mathrm{CDCl}_{3}\right): 0.93\left(3 \mathrm{H}, \mathrm{t}, J_{\mathrm{H}-\mathrm{H}}=7.6 \mathrm{~Hz}\right), 1.59(2 \mathrm{H}, \mathrm{m})$, $3.33\left(2 \mathrm{H}, \mathrm{t}, J_{\mathrm{H}-\mathrm{H}}=7.6 \mathrm{~Hz}\right), 3.62(2 \mathrm{H}, \mathrm{m}), 3.78(2 \mathrm{H}, \mathrm{m}), 8.08(1 \mathrm{H}$, bs); ${ }^{13} \mathrm{C}-\mathrm{NMR} \delta\left(\mathrm{CDCl}_{3}\right): 10.9,20.3,41.4,45.6,46.2,161.4$. MS $m / z(\%): 138\left(\mathrm{M}^{+}, 10\right), 130$ (12), 126 (100).

1-(2-Fluoroethyl)-2-(N-nitroimino)imidazolidine (2). Mp. $111^{\circ} \mathrm{C}$. ${ }^{1} \mathrm{H}-\mathrm{NMR} \delta\left(\mathrm{CDCl}_{3}\right): 3.68\left(2 \mathrm{H}, \mathrm{dt}, J_{\mathrm{H}-\mathrm{F}}=28.5 \mathrm{~Hz}, J_{\mathrm{H}-\mathrm{H}}=4.5 \mathrm{~Hz}\right)$, $3.81(4 \mathrm{H}, \mathrm{m}), 4.57\left(2 \mathrm{H}, \mathrm{dt}, J_{\mathrm{H}-\mathrm{F}}=47.3 \mathrm{~Hz}, J_{\mathrm{H}-\mathrm{H}}=4.5 \mathrm{~Hz}\right), 8.14$ $(1 \mathrm{H}, \mathrm{bs}) ;{ }^{13} \mathrm{C}-\mathrm{NMR} \mathrm{d}\left(\mathrm{CDCl}_{3}\right): 41.7,45.1\left(\mathrm{~d}, J_{\mathrm{C}-\mathrm{F}}=19.1 \mathrm{~Hz}\right), 47.4$, $82.3\left(\mathrm{~d}, J_{\mathrm{C}-\mathrm{F}}=169.1 \mathrm{~Hz}\right), 161.2 \mathrm{MS} m / z(\%): 176\left(\mathrm{M}^{+}, 13\right), 149$ (27), 130 (65), 110 (100).

1-(3-Chloropropyl)-2-(N-nitroimino)imidazolidine (4). Liquid. ${ }^{1} \mathrm{H}-\mathrm{NMR} \delta\left(\mathrm{CDCl}_{3}\right): 2.09(2 \mathrm{H}, \mathrm{m}), 3.50\left(2 \mathrm{H}, \mathrm{t}, J_{\mathrm{H}-\mathrm{H}}=7.1 \mathrm{~Hz}\right)$, $3.60\left(2 \mathrm{H}, \mathrm{t}, J_{\mathrm{H}-\mathrm{H}}=6.4 \mathrm{~Hz}\right), 3.68(2 \mathrm{H}, \mathrm{m}), 3.81(2 \mathrm{H}, \mathrm{m}), 8.10(1 \mathrm{H}$, bs); ${ }^{13} \mathrm{C}-\mathrm{NMR} \delta\left(\mathrm{CDCl}_{3}\right): 30.2,41.6,41.4,42.0,42.6,46.4$, 161.6. MS m/z (\%): $206\left(\mathrm{M}^{+}, 2\right), 171$ (20), 124 (80), 110 (100).

1-(3,3,3-Trifluoropropyl)-2-(N-nitroimino)imidazolidine (5). Mp. $95^{\circ} \mathrm{C} .{ }^{1} \mathrm{H}-\mathrm{NMR} \delta\left(\mathrm{CDCl}_{3}\right): 2.47(2 \mathrm{H}, \mathrm{m}), 3.59\left(2 \mathrm{H}, \mathrm{t}, J_{\mathrm{H}-\mathrm{H}}=\right.$ $6.9 \mathrm{~Hz}), 3.68(2 \mathrm{H}, \mathrm{m}), 3.81(2 \mathrm{H}, \mathrm{m}), 8.11(1 \mathrm{H}, \mathrm{bs}) ;{ }^{13} \mathrm{C}-\mathrm{NMR} \delta$ $\left(\mathrm{CDCl}_{3}\right): 31.7\left(\mathrm{q}, J_{\mathrm{C}-\mathrm{F}}=28.8 \mathrm{~Hz}\right), 38.4\left(\mathrm{q}, J_{\mathrm{C}-\mathrm{F}}=3.6 \mathrm{~Hz}\right), 41.6$, 46.2, 125.0 (q, $\left.J_{\mathrm{C}-\mathrm{F}}=279.1 \mathrm{~Hz}\right), 161.1 . \mathrm{MS} \mathrm{m} / \mathrm{z}(\%): 226\left(\mathrm{M}^{+}\right.$, 11), 180 (59), 140 (20), 138 (29), 42 (100).

1-(4-Fluorobutyl)-2-(N-nitroimino)imidazolidine (6). Liquid. ${ }^{1} \mathrm{H}-\mathrm{NMR} \delta\left(\mathrm{CDCl}_{3}\right): 1.73(4 \mathrm{H}, \mathrm{m}), 3.42\left(2 \mathrm{H}, \mathrm{t}, J_{\mathrm{H}-\mathrm{H}}=6.8 \mathrm{~Hz}\right)$, $3.64(2 \mathrm{H}, \mathrm{m}), 3.80(2 \mathrm{H}, \mathrm{m}), 4.49\left(2 \mathrm{H}, \mathrm{dt}, J_{\mathrm{H}-\mathrm{F}}=41.8, J_{\mathrm{H}-\mathrm{H}}=\right.$ $5.2 \mathrm{~Hz}), 8.11(1 \mathrm{H}, \mathrm{bs}) ;{ }^{13} \mathrm{C}-\mathrm{NMR} \delta\left(\mathrm{CDCl}_{3}\right): 23.1\left(\mathrm{~d}, J_{\mathrm{C}-\mathrm{F}}=\right.$ 
Table 1. Insecticidal potency in $\mathrm{ppm}^{a}$

\begin{tabular}{|c|c|c|c|c|c|c|c|c|c|}
\hline \multirow{2}{*}{ Compd } & \multicolumn{3}{|c|}{ Green peach aphid ${ }^{b)}$} & \multicolumn{3}{|c|}{ Tobacco cutworm ${ }^{c)}$} & \multicolumn{3}{|c|}{ Cucurbit leaf beetle $^{d)}$} \\
\hline & 500 & 100 & 20 & 500 & 100 & 20 & 500 & 100 & 20 \\
\hline 1 & 60 & & & 0 & & & 0 & & \\
\hline 2 & 60 & & & 0 & & & 0 & & \\
\hline 3 & 97 & 90 & 60 & 100 & 20 & $-f)$ & 100 & 100 & 0 \\
\hline 4 & 97 & 0 & & 0 & & - & 100 & 100 & 50 \\
\hline 5 & 0 & & & 30 & & & 100 & 50 & \\
\hline 6 & 97 & 60 & 0 & 20 & 0 & & $-f)$ & $-f)$ & $-f)$ \\
\hline 7 & 0 & & & 0 & & & 0 & & \\
\hline 9 & $-f)$ & 100 & 100 & 0 & & & $-f)$ & 100 & 100 \\
\hline $8^{e)}$ & 100 & 100 & 100 & 100 & 80 & 40 & 100 & 100 & 100 \\
\hline
\end{tabular}

${ }^{a)}$ Structure and rating, see Fig. 1 and the experimental section. ${ }^{b)}$ Myzus persicae.${ }^{c)}$ Spodoptera litura. ${ }^{d)}$ Aulacophora femoralis. ${ }^{e)}$ Imidacloprid. ${ }^{f)}$ Not tested.

$5.8 \mathrm{~Hz}), 27.3\left(\mathrm{~d}, J_{\mathrm{C}-\mathrm{F}}=20.4 \mathrm{~Hz}\right), 41.4,44.1,45.5,82.8\left(\mathrm{~d}, J_{\mathrm{C}-\mathrm{F}}=\right.$ 165.5 Hz), 161.3. MS m/z (\%): $204\left(\mathrm{M}^{+}, 1\right), 185$ (7), 174 (12), 158 (100), 138 (27), 130 (10), 124 (14).

1-(3,4,4-Trifluoro-3-butenyl)-2-(N-nitroimino)imidazolidine (7). Mp. $58-60^{\circ} \mathrm{C} .{ }^{1} \mathrm{H}-\mathrm{NMR} \delta\left(\mathrm{CDCl}_{3}\right): 2.00\left(2 \mathrm{H}, \mathrm{dm}, J_{\mathrm{H}-\mathrm{F}}=\right.$ $28.0 \mathrm{~Hz}), 3.58\left(2 \mathrm{H}, \mathrm{t}, J_{\mathrm{H}-\mathrm{H}}=6.8 \mathrm{~Hz}\right), 3.66(2 \mathrm{H}, \mathrm{m}), 3.82(2 \mathrm{H}, \mathrm{m})$, $8.13(1 \mathrm{H}, \mathrm{bs}) ;{ }^{13} \mathrm{C}-\mathrm{NMR} \delta\left(\mathrm{CDCl}_{3}\right): 24.3\left(\mathrm{~d}, J_{\mathrm{C}-\mathrm{F}}=21.6 \mathrm{~Hz}\right), 41.1$ $\left(\mathrm{d}, J_{\mathrm{C}-\mathrm{F}}=4.6 \mathrm{~Hz}\right), 41.6,46.2,127.3\left(\mathrm{td}, J_{\mathrm{C}-\mathrm{F}}=126.0 / 17.2 \mathrm{~Hz}\right)$, $153.4\left(\mathrm{td}, J_{\mathrm{C}-\mathrm{F}}=186.8 / 45.6 \mathrm{~Hz}\right), 161.3 . \mathrm{MS} m / z(\%): 239\left(\mathrm{M}^{+}+1\right.$, 66), 192 (77), 172 (21), 142 (100).

1-(6-Chloro-3-pyridylmethyl)-3-(3-fluoropropyl)-2-(N-nitroimino)imidazolidine (9). Mp. $78^{\circ} \mathrm{C} .{ }^{1} \mathrm{H}-\mathrm{NMR} \delta\left(\mathrm{CDCl}_{3}\right): 2.02$ $\left(2 \mathrm{H}, \mathrm{dm}, J_{\mathrm{H}-\mathrm{F}}=27.5 \mathrm{~Hz}\right), 3.46\left(2 \mathrm{H}, \mathrm{t}, J_{\mathrm{H}-\mathrm{H}}=7.2 \mathrm{~Hz}\right), 3.56(2 \mathrm{H}$, m), $3.75(2 \mathrm{H}, \mathrm{m}), 4.45(2 \mathrm{H}, \mathrm{s}), 4.50\left(2 \mathrm{H}, \mathrm{dt}, J_{\mathrm{H}-\mathrm{F}}=47.0, J_{\mathrm{H}-\mathrm{H}}=\right.$ $5.7 \mathrm{~Hz}), 7.32\left(1 \mathrm{H}, \mathrm{d}, J_{\mathrm{H}-\mathrm{H}}=8.0 \mathrm{~Hz}\right), 7.67\left(1 \mathrm{H}, \mathrm{dd}, J_{\mathrm{H}-\mathrm{H}}=\right.$ $8.0 / 2.3 \mathrm{~Hz}), 8.28\left(1 \mathrm{H}, \mathrm{d}, J_{\mathrm{H}-\mathrm{H}}=2.3 \mathrm{~Hz}\right) ;{ }^{13} \mathrm{C}-\mathrm{NMR} \delta\left(\mathrm{CDCl}_{3}\right)$ : $28.6\left(\mathrm{~d}, J_{\mathrm{C}-\mathrm{F}}=19.2 \mathrm{~Hz}\right), 44.9\left(\mathrm{~d}, J_{\mathrm{C}-\mathrm{F}}=3.6 \mathrm{~Hz}\right), 46.0,47.1,48.2$, $82.3\left(\mathrm{~d}, J_{\mathrm{C}-\mathrm{F}}=165.6 \mathrm{~Hz}\right), 125.7,129.9,140.0,150.2,152.7$, 162.1. MS $m / z(\%): 315\left(\mathrm{M}^{+}, 0.2\right), 285$ (10), 271 (58), 269 (100), 233 (37), 224 (52), 126 (73).

\section{Insecticidal assays}

2.1. Activity against the green peach aphid (Myzus persicae) About 30 heads per leaf of aphids of a mixed population were inoculated onto eggplants at the two-leaf stage. The next day, a water solution of the test compound was sprayed directly onto both insects and plants. On the seventh day after treatment, insecticidal activity was evaluated.

2.2. Activity against the tobacco cutworm (Spodoptera litura) A water solution of the test compound was sprayed onto cucumber seedlings at the two-leaf stage. After drying, the leaves were placed in a PET cup and about 20 1st-instar larvae of tobacco cutworm were released. The PET cup was covered with a lid and placed in a room kept at $25^{\circ} \mathrm{C}$. Mortality was determined on the seventh day and the percentage of insects killed was given as the activity rate.

2.3. Activity against the cucurbit leaf beetle (Aulacophora femoralis)

Two cucumber leaves $c a .8 \mathrm{~cm}$ in diameter were dipped into a water solution of the test compound for a few seconds until the leaf surface was wet. After drying, the leaves were placed on soil in a PET cup. Five 2nd-instar larvae were released into the cup. The cup was covered with a lid and stored at $25^{\circ} \mathrm{C}$. Activity was assessed on the seventh day after treatment.

\section{Results and Discussion}

The insecticidal activity against the green peach aphids, the tobacco cutworms and the cucurbit leaf beetles is listed in Table 1. The target insects of imidacloprid (8) are sucking insects, and $90 \%$ lethal dose at $0.32 \mathrm{ppm}$ for the aphid is recorded ${ }^{1)}$ (data not shown in Table 1). Propyl-substituted imidazolidine (1) showed only modest activity against the aphid. Halogen introduction to the terminal position of the alkyl chain led to compounds with variable insecticidal activity. The activity of the fluoroethyl derivative (2) was minimal, whereas fluoropropyl- (3) apparently and fluorobutyl derivative (6) significantly showed potency enhancement. In contrast, the 3-chloropropyl derivative (4) lacking the equivalent $\mathrm{H}$-bond-accepting atom did not exert such an evident enhancement, and trifluoromethyl and trifluorobutenyl derivatives 5 and 7 were inactive against the aphid.

The fluorine atom ranks first in electronegativity, and the $\sigma$ electrons on the conjunct alkyl chain flow to the terminal fluorine to a greater extent than to the chlorine atom in chloroalkyls. The $\mathrm{CF}_{3}$ group is also powerfully electronegative and the similar electron withdrawal is predicted; however, the portion of the electron gain for one fluorine atom will be smaller than that in the $\mathrm{CH}_{2} \mathrm{~F}$ 

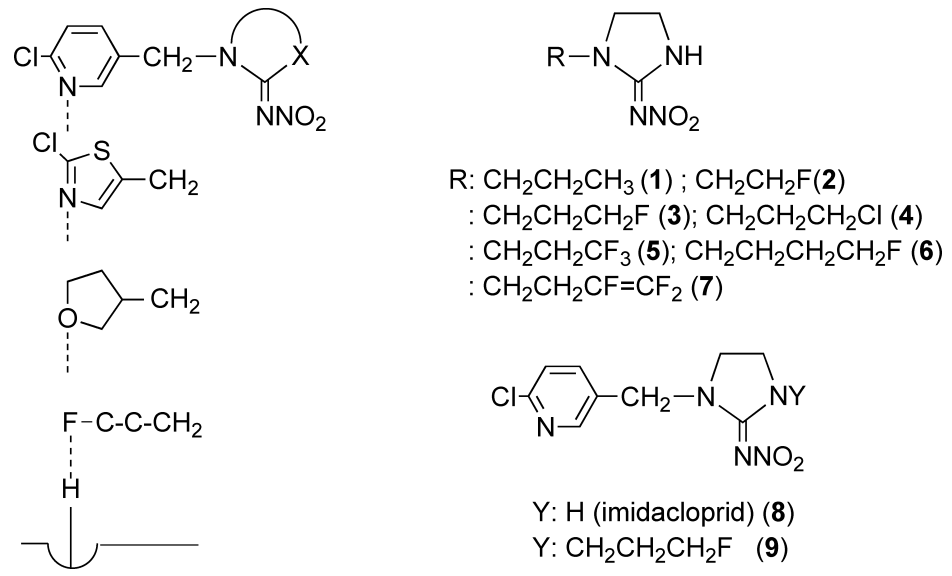

Fig. 1. Assumed H-bonding involving heteroatoms (left) and the tested compounds.

group. From the geometrical viewpoint, the distance from the fluorine atom to the imidazolidine $\mathrm{N}$-atom in a stretched chain conformation of compound (3) is close to the corresponding distances in the chloronicotinyl and the analogous molecules (Fig. 1). Also the $\mathrm{F}-\mathrm{N}$ distance in compound (6) is calculated to be able to reach the above distance with the chain bent. The above consideration made us assume that the fluorine atom of compounds $\mathbf{3}$ and $\mathbf{6}$ at this position could have functionality of an $\mathrm{H}-$ bond acceptor like the corresponding moiety of neonicotinoid molecules to elicit propitious effect on activity. Neonicotinoids are especially active against sucking insects and rather weak against biting insects. ${ }^{1)}$ Here, the similar insecticidal tendency of compounds 3 and $\mathbf{6}$ to imidacloprid (8) was also recognized although the potencies were far from the level of imidacloprid (Table 1).

Indeed, there is experimental evidence of the H-bond mediated by the C-F moiety. ${ }^{5,6)}$ On the other hand, however, overestimation of the H-bond strength of the fluorine atom in fluorocarbons has been called into question. ${ }^{7)}$ The H-bond magnitude by a fluorine atom may not be as large as expected for the present compounds. Another point to note concerns with the peculiar property, i.e. the polar hydrophobicity, of fluorocarbons, ${ }^{8)}$ which should be discriminated from the attributes of the hetero(aromatic) rings of neonicotinoid molecules.

Taken together, the effect of the fluorocarbon moiety is not compatible with that of the chloropyridylmethyl and analogous groups with a lipophilic plane moiety bearing a legitimate $\mathrm{H}$-bond-accepting atom of the existing neonicotinoid molecules. $N^{\prime}$-(3-Fluoropropyl)imidacloprid (9) showed high insecticidal ac- tivity against the aphid and the beetle, which may be further evidence of the necessity of the chloropyridyl moiety for activity. The question is at present open as to whether its activity is the result of the metabolic dealkylation to imidacloprid like the highly insecticidal $N^{\prime}$-propylimidacloprid. ${ }^{9)}$

\section{Acknowledgement}

This work was partly supported by a Grant-in-Aid for Scientific Research (C) (No. 17580094) from the Japan Society for the Promotion of Science.

\section{References}

1) S. Kagabu: Rev. Toxicol. 1, 75-129 (1997).

2) P. Jeschke and R. Nauen: "Comprehensive Molecular Insect Science,” Vol. 5, ed. by L. I. Gilbert, I. Lawrence, K. Iatrou and S. S. Gill, Elsevier, Oxford, pp. 53-105, 2005.

3) P. Jeschke: Chem. Bio. Chem. 5, 570-589 (2004).

4) M. B. Smith and J. March: "March's Advanced Organic Chemistry," 5th ed., Chap. 3, Wiley, New York, 2001.

5) W. P. Jencks: "Catalysts in Chemistry and Enzymology," Wiley, New York, p. 340, 1969.

6) C. Li, S.-F. Ren, J.-L. Hou, H.-P. Yi, S.-Z. Zhu, X.-K. Jiang and Z.-T. Li: Angew. Chem. Int. Ed. 44, 5725-5729 (2005).

7) G. A. Jeffrey: "Introduction to Hydrogen Bonding," Oxford Univ. Press, Oxford, Chapter 5, 1997.

8) J. C. Biffinger, H.-W. Kim and S. G. DiMagno: Chem. Bio. Chem. 5, 622-627 (2004).

9) K. Nishimura, M. Tanaka, K. Iwaya and S. Kagabu: Pestic. Biochem. Physiol. 62, 172-178 (1998). 